\title{
Consecutive cross-coupling reactions of 2,2-difluoro- 1-iodoethenyl tosylate with boronic acids: efficient synthesis of 1,1-diaryl-2,2-difluoroethenes
}

\author{
Ju Hee Kim, Su Jeong Choi and In Howa Jeong ${ }^{\star}$
}

\author{
Full Research Paper \\ Address: \\ Department of Chemistry \& Medical Chemistry, Yonsei University, \\ 1 Yonseidae-gil, Wonju, Gangwondo 220-710, Republic of Korea \\ Email: \\ In Howa Jeong* - jeongih@yonsei.ac.kr \\ * Corresponding author \\ Keywords: \\ boronic acids; cross-coupling reaction; 1,1-diaryl-2,2-difluoroethene; \\ 1,1-difluoro-1,3-dienes; 2,2-difluoro-1-iodoethenyl tosylate; \\ organo-fluorine
}

Open Access

\author{
Beilstein J. Org. Chem. 2013, 9, 2470-2475. \\ doi:10.3762/bjoc. 9.286 \\ Received: 27 August 2013 \\ Accepted: 22 October 2013 \\ Published: 14 November 2013 \\ This article is part of the Thematic Series "Organo-fluorine chemistry III". \\ Guest Editor: D. O'Hagan \\ (c) 2013 Kim et al; licensee Beilstein-Institut. \\ License and terms: see end of document.
}

\begin{abstract}
The cross-coupling reactions of 2,2-difluoro-1-iodoethenyl tosylate (2) with 2 equiv of boronic acids in the presence of catalytic amounts of $\mathrm{Pd}(\mathrm{OAc})_{2}$ and $\mathrm{Na}_{2} \mathrm{CO}_{3}$ afforded the mono-coupled products $\mathbf{3}$ and $\mathbf{5}$ in high yields. The use of 4 equiv of boronic acids in the presence of catalytic amount of $\mathrm{Pd}\left(\mathrm{PPh}_{3}\right)_{2} \mathrm{Cl}_{2}$ and $\mathrm{Na}_{2} \mathrm{CO}_{3}$ in this reaction resulted in the formation of symmetrical di-coupled products 4 in high yields. Unsymmetrical di-coupled products 4 were obtained in high yields from the reactions of 3 with 2 equiv of boronic acids in the presence of catalytic amounts of $\mathrm{Pd}(\mathrm{OAc})_{2}$ and $\mathrm{Na}_{2} \mathrm{CO}_{3}$.
\end{abstract}

\section{Introduction}

The synthesis of 2,2-disubstituted-1,1-difluoroethenes have received much attention to synthetic organofluorine chemists in recent years because of their unique chemical reactivities toward nucleophiles to produce monofluorinated organic compounds [1-4], and their biological activity, such as mechanismbased enzyme inhibitors, in the area of medicinal chemistry [5-8]. The 1,1-difluoroethenylidene functionality in these compounds is also known to act as a bioisostere for the carbonyl group of many biologically active compounds [9-12]. Although numerous methods for the preparation of 2,2-disubstituted-1,1difluoroethenes have been reported in the previous literature [13-22], a consecutive cross-coupling reaction of a proper precursor such as a 1,1-difluoroethenylidene species bearing a metal functional group, a halogen substituent or a tosylate group at the vinyl carbon will provide a concise and efficient method for the synthesis of 2,2-disubstituted-1,1-difluoroethenes. Burton et al. reported a straightforward method for the preparation of 1,1-diaryl-2,2-difluoroethenes from the consecutive cross-coupling reaction of the 2,2-difluoro-1-bromoethenylzinc reagent with aryl iodides, followed by arylboronic acids [17]. Recently, we also prepared 2,2-difluoro-1-tributylstannylethenyl tosylate and (2,2-difluoroethenyl-idene)bis(tributylstannane) which were utilized in the palladium-catalyzed consecutive cross-coupling reactions with electrophilic aryl iodides or nucleophilic arylstannane reagents to afford the corresponding 1,1-diaryl-2,2-difluoroethenes [20,21]. However, 
these previous reagents still have some drawbacks such as the existence of the toxic tributylstannyl group, thermal instability of ethenylzinc reagents and the use of at least one nucleophilic reactive site for the coupling partner. In contrast to these reagents, the 1,1-difluoroethenylidene species bearing both an electrophilic halogen substituent and a tosylate group at the vinyl carbon have not been studied in the cross-coupling reaction with stable and less toxic nucleophilic metal reagents such as aryl- and alkenylboronic acids. Herein, we report a preparation of 2,2-difluoro-1-iodoethenyl tosylate and its crosscoupling reactions with aryl- and alkenylboronic acids to give the corresponding 1,1-difluoroalkenes.

\section{Results and Discussion}

Although the chemistry of the 2,2-difluoroethenylidene species as a building block has been well established in recent years, 2,2-difluoro-1-iodoethenyl tosylate (2) was not previously prepared. However, we easily synthesized the starting material 2 from the reaction of 2,2,2-trifluoroethyl tosylate (1) with 2 equiv of LDA in THF at $-78^{\circ} \mathrm{C}$, followed by treatment with 1 equiv of iodine (Scheme 1).

First, we attempted the consecutive palladium-catalyzed crosscoupling reaction of $\mathbf{2}$ with different arylboronic acids to afford unsymmetrical 1,1-diaryl-2,2-difluoroethenes. Since the use of a proper base in the Suzuki-Miyaura reaction is an important factor to increase the yield of coupled product, we screened bases to get the optimized reaction conditions. When 2 was

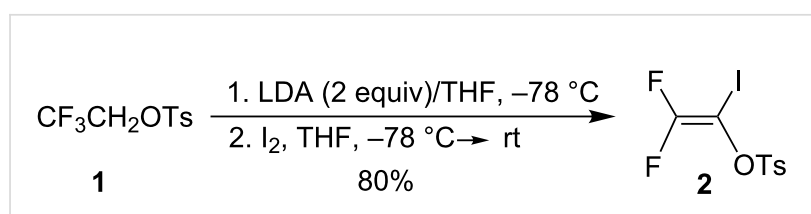

Scheme 1: Preparation of 2,2-difluoro-1-iodoethenyl tosylate (2).

reacted with 1 equiv of phenylboronic acid in the presence of $5 \mathrm{~mol} \%$ of $\mathrm{Pd}(\mathrm{OAc})_{2}$ and $\mathrm{Cs}_{2} \mathrm{CO}_{3}$ (2 equiv) in methanol at room temperature for $15 \mathrm{~h}$, mono- and di-coupled products $3 \mathbf{a}$ and $4 \mathbf{a}$ were obtained in $21 \%$ and $10 \%$ yields, respectively, along with a small amount of the self-coupled product (less than $5 \%$ ) and reduced product. The use of 2 equiv of phenylboronic acid in the same reaction increased the yield of $\mathbf{3 a}(38 \%)$ and $4 \mathbf{a}$ $(19 \%)$. However, the use of high molecular amounts of Pd catalyst did not improve the yield of $\mathbf{3}$. The same reaction was performed with $\mathrm{K}_{2} \mathrm{CO}_{3}$ instead of $\mathrm{Cs}_{2} \mathrm{CO}_{3}$ as a base to give $\mathbf{3 a}$ and $4 \mathrm{a}$ in $56 \%$ and $16 \%$ yields. The use of $\mathrm{K}_{3} \mathrm{PO}_{4}$ in this reaction provided similar results. Finally, the optimized reaction condition was achieved by using $\mathrm{Na}_{2} \mathrm{CO}_{3}$ as a base, in which only mono-coupled product $\mathbf{3 a}$ was obtained in $92 \%$ yield along with the self-coupled product derived from the excess boronic acid. When the reaction was performed in the presence of $5 \%$ $\mathrm{Pd}\left(\mathrm{PPh}_{3}\right)_{2} \mathrm{Cl}_{2}$ or $\mathrm{Pd}\left(\mathrm{CH}_{3} \mathrm{CN}\right)_{2} \mathrm{Cl}_{2}$ instead of $\mathrm{Pd}(\mathrm{OAc})_{2}$, di-coupled product $4 \mathbf{a}$ was always formed in 6-13\% yield. Optimization of the cross-coupling reaction of 2 with phenylboronic acid is summarized in Table 1 .

Table 1: Optimization of the cross-coupling reaction of 2 with phenylboronic acid.

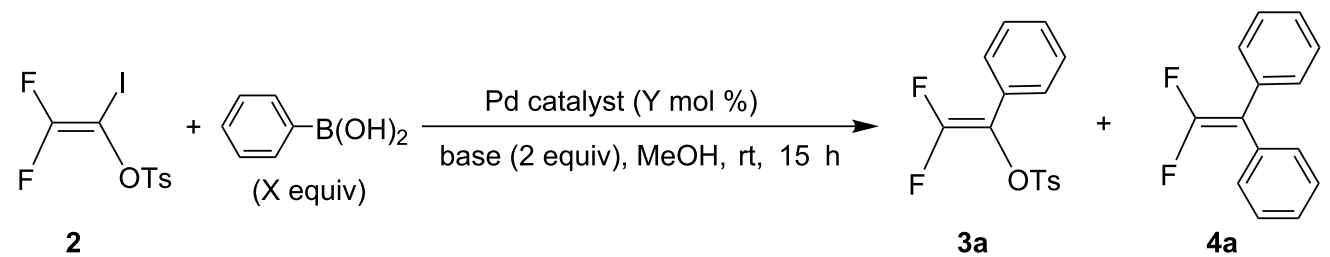

2

$3 a$

$4 a$

\begin{tabular}{|c|c|c|c|c|c|c|}
\hline \multirow[t]{2}{*}{ Entry } & \multirow[t]{2}{*}{ Pd catalyst } & \multirow[t]{2}{*}{$X$ (equiv) } & \multirow[t]{2}{*}{$\mathrm{Y}(\mathrm{mol} \%)$} & \multirow[t]{2}{*}{ Base } & \multicolumn{2}{|c|}{ Yield (\%) ${ }^{a}$} \\
\hline & & & & & $3 a$ & $4 a$ \\
\hline 1 & $\mathrm{Pd}(\mathrm{OAc})_{2}$ & 1 & 5 & $\mathrm{Cs}_{2} \mathrm{CO}_{3}$ & 21 & 10 \\
\hline 2 & $\mathrm{Pd}(\mathrm{OAc})_{2}$ & 2 & 5 & $\mathrm{Cs}_{2} \mathrm{CO}_{3}$ & 38 & 19 \\
\hline 3 & $\mathrm{Pd}(\mathrm{OAc})_{2}$ & 3 & 5 & $\mathrm{Cs}_{2} \mathrm{CO}_{3}$ & 18 & 40 \\
\hline 4 & $\mathrm{Pd}(\mathrm{OAc})_{2}$ & 2 & 10 & $\mathrm{Cs}_{2} \mathrm{CO}_{3}$ & 30 & 24 \\
\hline 5 & $\mathrm{Pd}(\mathrm{OAc})_{2}$ & 2 & 5 & $\mathrm{~K}_{2} \mathrm{CO}_{3}$ & 56 & 16 \\
\hline 6 & $\mathrm{Pd}(\mathrm{OAc})_{2}$ & 2 & 5 & $\mathrm{~K}_{3} \mathrm{PO}_{4}$ & 54 & 17 \\
\hline 7 & $\mathrm{Pd}(\mathrm{OAc})_{2}$ & 2 & 5 & $\mathrm{Na}_{2} \mathrm{CO}_{3}$ & 92 & $-{ }^{b}$ \\
\hline 8 & $\mathrm{Pd}\left(\mathrm{PPh}_{3}\right)_{2} \mathrm{Cl}_{2}$ & 2 & 5 & $\mathrm{Na}_{2} \mathrm{CO}_{3}$ & 78 & 6 \\
\hline 9 & $\mathrm{Pd}\left(\mathrm{CH}_{3} \mathrm{CN}\right)_{2} \mathrm{Cl}_{2}$ & 2 & 5 & $\mathrm{Na}_{2} \mathrm{CO}_{3}$ & 55 & 13 \\
\hline
\end{tabular}

alsolated yield. ${ }^{\mathrm{b}} \mathrm{A}$ trace amount of $\mathbf{4 a}$ was obtained. 
After the successful coupling reaction of $\mathbf{2}$ with phenylboronic acid under the optimized reaction conditions, the same reaction was performed with other arylboronic acids bearing a proton, fluoro, chloro, methyl, methoxy and trifluoromethyl on the ortho-, meta- or para-position of the benzene ring. Reactions were successful with both electron-donating and electron-withdrawing arylboronic acids to produce the corresponding 2,2difluoro-1-arylethenyl tosylates 3 in excellent isolated yields. Especially, the coupling reactions with arylboronic acids having an electron-donating group at the ortho-position of the benzene ring also provided the corresponding coupled products $\mathbf{3} \mathbf{I}-\mathbf{n}$ in good yields. The cross-coupling reactions of $\mathbf{2}$ with arylboronic acids are summarized in Table 2 .

Direct diarylation reactions of $\mathbf{2}$ with arylboronic acids were also performed because di-coupled product $\mathbf{4 a}$ was formed in a mono-arylation reaction (Table 1) and also a recent work showed a successful cross-coupling reaction of nonfluorinated enol tosylates with a variety of arylboronic acids [23]. We attempted a direct diarylation reaction of $\mathbf{2}$ with phenylboronic acid to establish the optimized reaction conditions. Initial reaction of 2 with 3 equiv of phenylboronic acid in the presence of $5 \mathrm{~mol} \%$ of $\mathrm{Pd}(\mathrm{OAc})_{2}$ and 2 equiv of $\mathrm{Na}_{2} \mathrm{CO}_{3}$ in $\mathrm{MeOH}$ at room temperature for $22 \mathrm{~h}$ afforded the di-coupled product $4 \mathbf{a}$ in $30 \%$ yield. The yield of $\mathbf{4 a}$ was increased to $39 \%$ using 4 equiv of phenylboronic acid in this reaction. When the reaction was performed with $\mathrm{K}_{2} \mathrm{CO}_{3}$ or $\mathrm{K}_{3} \mathrm{PO}_{4}$ as a base under the same reaction conditions, the desired product $\mathbf{4 a}$ was obtained in up to $49-52 \%$ yield. The use of more soluble $\mathrm{Cs}_{2} \mathrm{CO}_{3}$ resulted in the formation of $4 \mathbf{a}$ in $61 \%$ yield. Increasing the reaction temperature did not improve the of yield of $\mathbf{4 a}$. We also examined the effect of the palladium catalyst in this reaction. Therefore, the same reaction was performed in the presence of $5 \mathrm{~mol} \%$ of $\mathrm{Pd}\left(\mathrm{PPh}_{3}\right)_{2} \mathrm{Cl}_{2}$ instead of $\mathrm{Pd}(\mathrm{OAc})_{2}$, in which $4 \mathbf{a}$ was obtained in $75 \%$ yield. Other palladium catalysts such as $\mathrm{Pd}\left(\mathrm{CH}_{3} \mathrm{CN}\right)_{2} \mathrm{Cl}_{2}$ did not cause to improve the yield of 4a. Optimization of the di-coupling reaction of $\mathbf{2}$ with phenylboronic acid is summarized in Table 3 .

Diarylation reactions of $\mathbf{2}$ with arylboronic acids substituted by fluoro, chloro, methyl, methoxy, nitro and trifluoromethyl substituent at the meta- or para-position of the benzene ring proceeded well under the optimized reaction conditions to give the corresponding symmetrical di-coupled products $\mathbf{4 b}-\mathbf{k}$ in 51-86\% yield. However, coupling reactions with arylboronic acids having a substituent such as chloro, methyl or a methoxy group at the ortho-position of the benzene ring to produce the di-coupled products 4l-n were unsuccessful. This result probably indicates that the coupling process could be affected by steric hindrance in the second coupling reaction step. The di-coupling reactions of $\mathbf{2}$ with arylboronic acids are summarized in Table 4.

Table 2: Preparation of 2,2-difluoro-1-arylethenyl tosylate 3.<smiles>[OH2+]C(I)=C(F)F</smiles>

2<smiles>[R]c1cccc(Br)c1</smiles>

(2 equiv)
$\mathrm{Pd}(\mathrm{OAc})_{2}(5 \mathrm{~mol} \%) / \mathrm{Na}_{2} \mathrm{CO}_{3}$ (2 equiv)

$\mathrm{MeOH}, \mathrm{rt}, t$

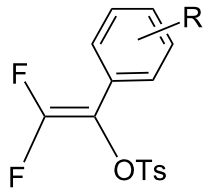

3a-n

\begin{tabular}{|c|c|c|c|}
\hline Compound & $\mathrm{R}$ & $t(\mathrm{~h})$ & Yield $(\%)^{a}$ \\
\hline $3 a$ & $\mathrm{H}$ & 15 & 92 \\
\hline $3 b$ & $p-\mathrm{F}$ & 15 & 81 \\
\hline $3 c$ & $p-\mathrm{Cl}$ & 14 & 84 \\
\hline $3 d$ & $p-\mathrm{CH}_{3}$ & 14 & 79 \\
\hline $3 e$ & $p-\mathrm{OCH}_{3}$ & 14 & 65 \\
\hline $3 f$ & $p-\mathrm{CF}_{3}$ & 15 & 85 \\
\hline $3 g$ & $m-\mathrm{F}$ & 16 & 72 \\
\hline $3 h$ & $m-\mathrm{Cl}$ & 16 & 76 \\
\hline $3 \mathbf{i}$ & $m-\mathrm{CH}_{3}$ & 16 & 82 \\
\hline $3 \mathbf{j}$ & $m-\mathrm{OCH}_{3}$ & 18 & 74 \\
\hline $3 k$ & $m-\mathrm{CF}_{3}$ & 18 & 80 \\
\hline 31 & $o-\mathrm{CH}_{3}$ & 18 & 65 \\
\hline $3 m$ & $\mathrm{o}-\mathrm{OCH}_{3}$ & 18 & 61 \\
\hline $3 n$ & $\mathrm{o}-\mathrm{Cl}$ & 18 & 68 \\
\hline
\end{tabular}

alsolated yield. 
Table 3: Optimization of the di-coupling reaction of $\mathbf{2}$ with phenylboronic acid.

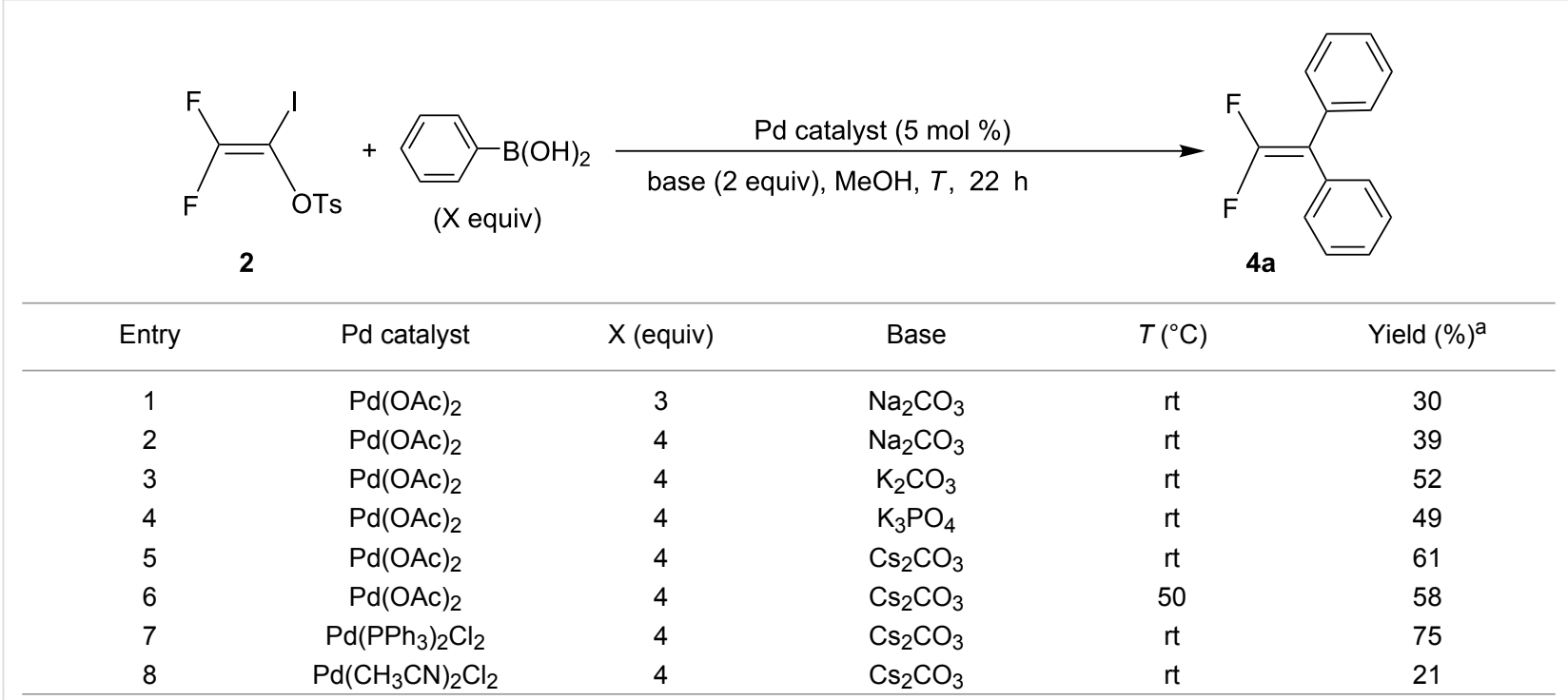

asolated yield of $\mathbf{4 a}$.

Table 4: Preparation of symmetrical 1,1-diaryl-2,2-difluoroethenes 4.

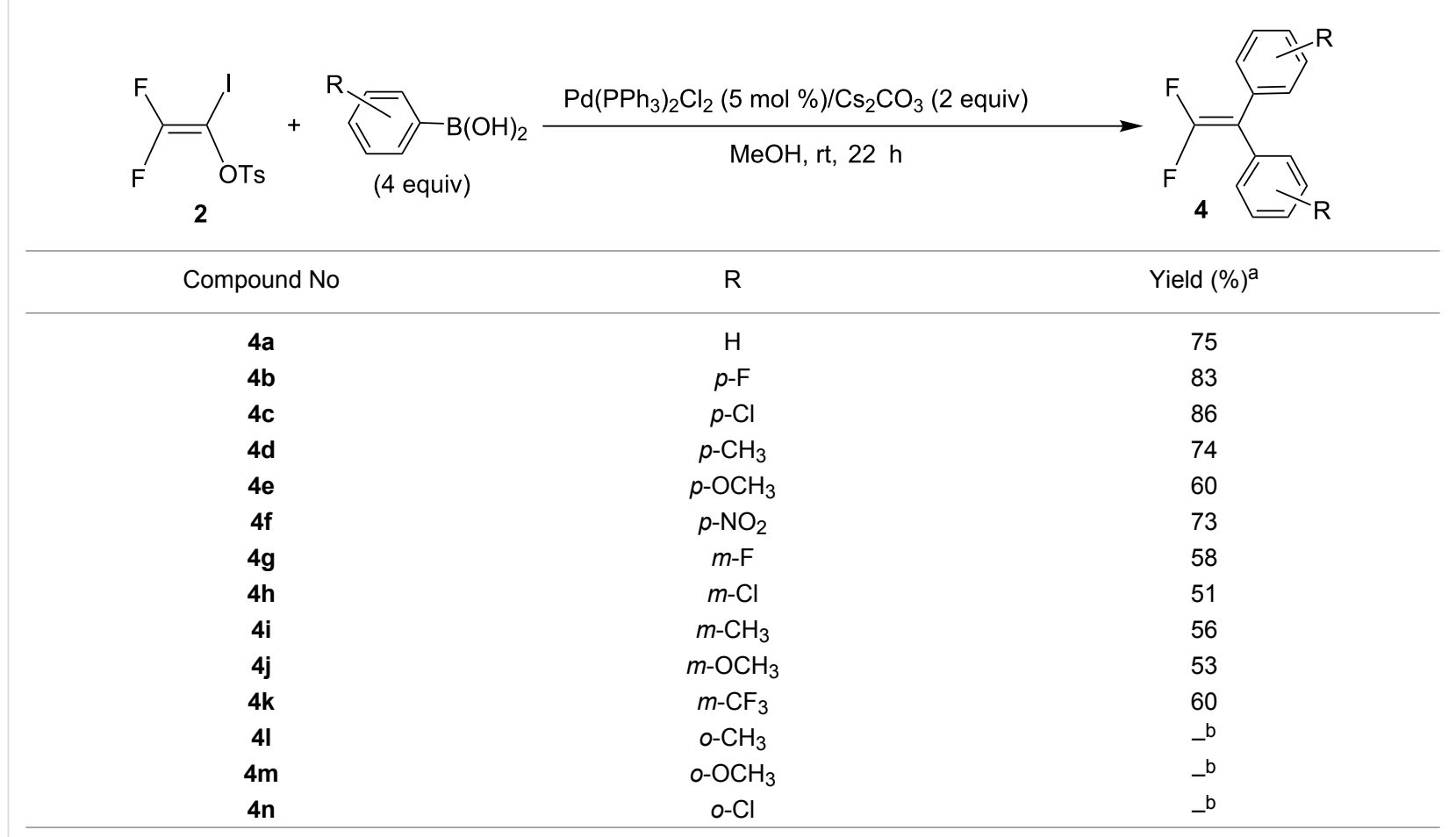

alsolated yield. ${ }^{\mathrm{b}} \mathrm{A}$ trace amount of product was obtained.

Unsymmetrical 1,1-diaryl-2,2-difluoroethenes can be prepared from the coupling reaction of mono-coupled tosylates 3 with arylboronic acids under similar reaction conditions. Therefore, the cross-coupling reaction of $\mathbf{3 a}$ with 2 equiv of $p$-chloro- phenylboronic acid in the presence of $5 \mathrm{~mol} \% \mathrm{Pd}\left(\mathrm{PPh}_{3}\right)_{2} \mathrm{Cl}_{2}$ and 2 equiv of $\mathrm{Cs}_{2} \mathrm{CO}_{3}$ in $\mathrm{MeOH}$ at room temperature for $12 \mathrm{~h}$ afforded 1,1-diaryl-2,2-difluoroethene 40 in $89 \%$ yield. The similar reactions of $\mathbf{3} \mathbf{a}$ with arylboronic acids having a 
substituent such as fluoro, methyl, methoxy, and trifluoromethyl at the meta- or para-position of the benzene ring also provided the corresponding 1,1-diaryl-2,2-difluoroethenes $\mathbf{4 p - \mathbf { v }}$ in $75-90 \%$ yields. The coupling reaction between $3 \mathbf{c}$ and $m$-methylphenylboronic acid also resulted in the formation of $\mathbf{4 w}$ in $\mathbf{7 9 \%}$ yield. Similarly, $\mathbf{3 k}$ having an electron-withdrawing group on the benzene ring was also reacted with $p$-methylphenylboronic acid to yield $\mathbf{4 x}$ in $70 \%$ yield. Table 5 summarizes the results of the coupling reactions of $\mathbf{3}$ with several arylboronic acids to give unsymmetrical 1,1-diaryl-2,2-difluoroethenes.

The successful cross-coupling reaction of $\mathbf{2}$ with arylboronic acids prompted us to examine similar coupling reactions with alkenylboronic acids. The same reaction conditions of the mono-coupling reaction of $\mathbf{2}$ with arylboronic acid was applied to the alkenylation of $\mathbf{2}$. Therefore, the cross-coupling reaction of 2 with trans-2-phenylethenylboronic acid in the presence of $5 \mathrm{~mol} \%$ of $\mathrm{Pd}(\mathrm{OAc})_{2}$ and 2 equiv of $\mathrm{Na}_{2} \mathrm{CO}_{3}$ in $\mathrm{MeOH}$ at room temperature for $15 \mathrm{~h}$ provided the cross-coupled product $5 \mathrm{a}$ in $85 \%$ yield. The similar reaction of 2 with trans-oct-1-enylboronic acid afforded the cross-coupled product $\mathbf{5 b}$ in $81 \%$ yield. The cross-coupling reactions of 2 with alkenylboronic acids are summarized in Table 6.

\section{Conclusion}

In summary, we have successfully developed the consecutive cross-coupling reactions of 2,2-difluoro-1-iodoethenyl tosylate

Table 5: Preparation of unsymmetrical 1,1-diaryl-2,2-difluoroethenes 4<smiles>[R]c1cccc(C([O-])=C(F)F)c1</smiles>

3<smiles></smiles>

(2 equiv)

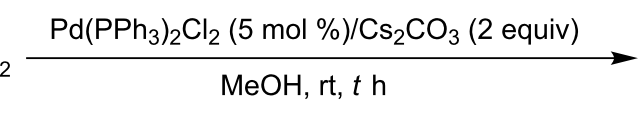

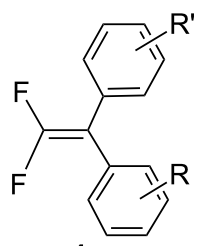

4

\begin{tabular}{|c|c|c|c|c|}
\hline Compound No & $\mathrm{R}$ & $\mathrm{R}^{\prime}$ & $T(\mathrm{~h})$ & Yield $(\%)^{a}$ \\
\hline 40 & $\mathrm{H}$ & $p-\mathrm{Cl}$ & 12 & 89 \\
\hline $4 p$ & $\mathrm{H}$ & $p-\mathrm{F}$ & 12 & 90 \\
\hline $4 q$ & $\mathrm{H}$ & $p-\mathrm{CH}_{3}$ & 12 & 81 \\
\hline $4 r$ & $\mathrm{H}$ & $p-\mathrm{OCH}_{3}$ & 14 & 79 \\
\hline $4 \mathrm{~s}$ & $\mathrm{H}$ & $p-\mathrm{CF}_{3}$ & 18 & 82 \\
\hline $4 t$ & $\mathrm{H}$ & $m-\mathrm{Cl}$ & 12 & 81 \\
\hline $4 u$ & $\mathrm{H}$ & $m-\mathrm{CH}_{3}$ & 14 & 77 \\
\hline $4 v$ & $\mathrm{H}$ & $m-\mathrm{CF}_{3}$ & 14 & 75 \\
\hline $4 w$ & $p-\mathrm{Cl}$ & $m-\mathrm{CH}_{3}$ & 12 & 79 \\
\hline $4 x$ & $m-\mathrm{CF}_{3}$ & $p-\mathrm{CH}_{3}$ & 12 & 70 \\
\hline
\end{tabular}

alsolated yield.

Table 6: The cross-coupling reactions of $\mathbf{2}$ with alkenylboronic acids.

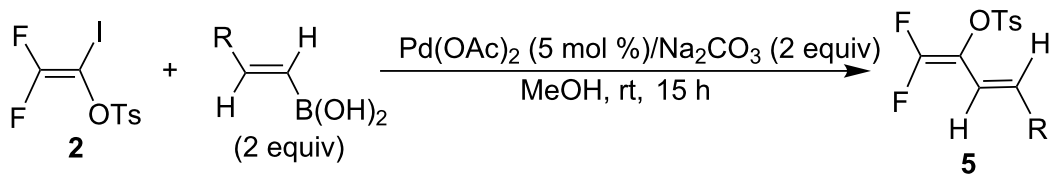

\begin{tabular}{ccc}
\hline Compound No. & $\mathrm{R}$ & Yield (\%) \\
\hline $\mathbf{5 a}$ & $\mathrm{Ph}$ & 85 \\
$\mathbf{5 b}$ & $\mathrm{CH}_{3}\left(\mathrm{CH}_{2}\right)_{5}$ & 81 \\
\hline
\end{tabular}

alsolated yield. 
(2) with arylboronic or alkenylboronic acids in the presence of a suitable Pd catalyst and a base to afford 2,2-diaryl-1,1-difluoroethenes. The developed method provides synthetically useful advantages such as a straightforward procedure to give symmetrical and unsymmetrical 2,2-diaryl-1,1-difluoroethenes and the use of a less toxic reagent such as boronic acid.

\section{Supporting Information}

\section{Supporting Information File 1}

Experimental details, full spectroscopic data and spectra.

[http://www.beilstein-journals.org/bjoc/content/

supplementary/1860-5397-9-286-S1.pdf]

\section{Acknowledgements}

This work was supported by a Basic Research Grant (20120008411) funded by the National Research Foundation of Korea.

\section{References}

1. Ichikawa, J.; Wada, Y.; Okauchi, T.; Minami, T. Chem. Commun. 1997, 1537-1538. doi:10.1039/a703110f

2. Ichikawa, J.; Wada, Y.; Fujiwara, M.; Sakoda, K. Synthesis 2002, 1917-1936. doi:10.1055/s-2002-33912

3. Ichikawa, J.; Miyazaki, H.; Sakoda, K.; Wada, Y. J. Fluorine Chem. 2004, 125, 585-593. doi:10.1016/j.jluchem.2004.01.004

4. Ichikawa, J.; Sakoda, K.; Moriyama, H.; Wada, Y. Synthesis 2006, 1590-1598. doi:10.1055/s-2006-926458

5. McDonald, I. A.; Lacoste, J. M.; Bey, P.; Palfreyman, M. G.; Ziena, M. J. Med. Chem. 1985, 28, 186-193. doi:10.1021/jm00380a007

6. Madden, B. A.; Prestwich, D. G. Bioorg. Med. Chem. Lett. 1997, 7, 309-314. doi:10.1016/S0960-894X(97)00008-5

7. Weintraub, P. M.; Holland, A. K.; Gate, C. A.; Moore, W. R.; Resvick, R. J.; Bey, P.; Peet, N. P. Bioorg. Med. Chem. 2003, 11, 427-431. doi:10.1016/S0968-0896(02)00434-0

8. Landelle, G.; Turcotte-Savard, M.-O.; Marterer, J.; Champagne, P. A.; Paquin, J.-F. Org. Lett. 2009, 11, 5406-5409. doi:10.1021/ol9022672

9. Bobek, M.; Kavai, I.; De Clercq, E. J. Med. Chem. 1987, 30, 1494-1497. doi:10.1021/jm00391a036

10. Moore, W. R.; Schatzman, G. L.; Jarvi, E. T.; Gross, R. S.; McCarthy, J. R. J. Am. Chem. Soc. 1992, 114, 360-361. doi:10.1021/ja00027a056

11. Altenburger, J.-M.; Lassalle, G. Y.; Matrougui, M.; Galtier, D.; Jetha, J.-C.; Bocskei, Z.; Berry, C. N.; Lunven, C.; Lorrain, J.; Herault, J.-P.; Schaeffer, P.; O'Connor, S. E.; Herbert, J.-M. Bioorg. Med. Chem. 2004, 12, 1713-1730. doi:10.1016/j.bmc.2004.01.016

12. Ichikawa, J. J. Synth. Org. Chem., Jpn. 2010, 68, 1175-1184. doi:10.5059/yukigoseikyokaishi.68.1175

13. Lee, J.; Tsukazaki, M.; Snieckus, V. Tetrahedron Lett. 1993, 34, 415-418. doi:10.1016/0040-4039(93)85090-J

14. Ichikawa, J. J. Fluorine Chem. 2000, 105, 257-263. doi:10.1016/S0022-1139(99)00268-7

15. DeBoos, G. A.; Fullbrook, J. J.; Percy, J. M. Org. Lett. 2001, 3, 2859-2861. doi:10.1021/ol010135p
16. Ichikawa, J.; Ishibashi, Y.; Fukui, H. Tetrahedron Lett. 2003, 44, 707-710. doi:10.1016/S0040-4039(02)02652-7

17. Raghavanpillai, A.; Burton, D. J. J. Org. Chem. 2006, 71, 194-201. doi:10.1021/jo051842p

18. Choi, J. H.; Jeong, I. H. Tetrahedron Lett. 2008, 49, 952-955. doi:10.1016/j.tetlet.2007.12.028

19. Zhao, Y.; Huang, W.; Zhu, L.; Hu, J. Org. Lett. 2010, 12, 1444-1447. doi:10.1021/ol100090r

20. Han, S. Y.; Jeong, I. H. Org. Lett. 2010, 12, 5518-5521. doi:10.1021/ol1024037

21. Han, S. Y.; Lee, H. Y.; Jeon, J. H.; Jeong, I. H. Tetrahedron Lett. 2012, 53, 1833-1836. doi:10.1016/j.tetlet.2012.01.127

22. Turcotte-Savard, M.-O.; Paquin, J.-F. Org. Biomol. Chem. 2013, 11, 1367-1375. doi:10.1039/c2ob27221k

23. Steinhuebel, D.; Baxter, J. M.; Palucki, M.; Davies, I. W. J. Org. Chem. 2005, 70, 10124-10127. doi:10.1021/jo051590s

\section{License and Terms}

This is an Open Access article under the terms of the Creative Commons Attribution License

(http://creativecommons.org/licenses/by/2.0), which permits unrestricted use, distribution, and reproduction in any medium, provided the original work is properly cited.

The license is subject to the Beilstein Journal of Organic Chemistry terms and conditions:

(http://www.beilstein-journals.org/bjoc)

The definitive version of this article is the electronic one which can be found at: doi:10.3762/bjoc.9.286 